Journal of Organometallic Chemistry, 415 (1991) 39-45

Elsevier Sequoia S.A., Lausanne

JOM 21852

\title{
Synthesis and enantioselective enzymatic hydrolysis of rac-dimethylphenyl[1-(phenylacetamido)ethyl]silane
}

\author{
Heidi Hengelsberg, Reinhold Tacke * \\ Institut für Anorganische Chemie, Universität Karlsruhe, Engesserstraße, Geb. 30.45, \\ W.7500 Karlsruhe I (Germany) \\ Kirsten Fritsche, Christoph Syldatk and Fritz Wagner \\ Institut für Biochemie und Biotechnologie A, Technische Universität Braunschweig, \\ Konstantin-Uhde-Straße 5, W-3300 Braunschweig (Germany)
}

(Received March 13th, 1991)

\begin{abstract}
Racemic dimethylphenyl[1-(phenylacetamido)ethyl]silane [rac-5] has been made by a four-step synthesis starting from (chloromethyl)dimethylphenylsilane $\left[\mathrm{PhMe}_{2} \mathrm{SiCH}_{2} \mathrm{Cl}(1) \rightarrow \mathrm{PhMe}_{2} \mathrm{SiCH}(\mathrm{Cl}) \mathrm{Me}\right.$ $\left(\right.$ rac-2) $\rightarrow \mathrm{PhMe}_{2} \mathrm{SiCH}(\mathrm{I}) \mathrm{Me} \quad($ rac-3 $) \rightarrow \mathrm{PhMe}_{2} \mathrm{SiCH}\left(\mathrm{NH}_{2}\right) \mathrm{Me} \quad\left(\right.$ rac-4) $\rightarrow \mathrm{PhMe}_{2} \operatorname{SiCH}[\mathrm{N}(\mathrm{H}) \mathrm{C}(\mathrm{O})$ $\mathrm{CH}_{2} \mathrm{Ph}$ ]Me (rac-5); total yield 41\%]. Enantioselective enzymatic hydrolysis of rac-5, catalyzed by immobilized penicillin $\mathrm{G}$ acylase (E.C. 3.5.1.11) from Escherichia coli 5K (pHM 12), gave ( $R$ )-(1aminoethyl)dimethylphenylsilane $[(R)-4]$ in $40 \%$ yield with an enantiomeric purity of $92 \%$ ee.
\end{abstract}

\section{Introduction}

During our investigations on the synthesis of optically active organosilicon compounds by use of stereoselective biotransformations, both whole microbial cells [1-6] and free enzymes [7] were used as biocatalysts (for recent reviews see refs. 8-10). The types of reactions studied so far comprise enantioselective reductions, ester hydrolyses, and transesterifications. We report here the enzymatic synthesis of $(R)$-(1-aminoethyl)dimethylphenylsilane $[(R)-4]$ starting from racemic dimethylphenyl[1-(phenylacetamido)ethyl]silane (rac-5). The optically active (1aminoethyl)silane ( $R$ )-4 was obtained by a kinetic resolution of rac-5 using immobilized penicillin G acylase (PGA, E.C. 3.5.1.11) from Escherichia coli 5K (pHM 12) as biocatalyst (for a preliminary report on this reaction, see ref. 11). This type of enzymatic reaction (amide hydrolysis) has not previously been used for the preparation of optically active organosilicon compounds.

\section{Results and discussion}

\section{Synthesis of rac-5}

Compound rac-5 was made by a four-step route starting from (chloromethyl)dimethylphenylsilane (1), as outlined in Scheme 1. Following a procedure described in 
<smiles>C[Si](C)(CCl)c1ccccc1</smiles>

$$
\begin{aligned}
& \text { 1. } \sec -\mathrm{LIC}_{4} \mathrm{H}_{0} \text { (TMEDA) } \\
& \text { 2. } \mathrm{CH}_{3} \mathrm{I}
\end{aligned}
$$<smiles>CC(Cl)[Si](C)(C)c1ccccc1</smiles>

rac -2

Nol<smiles>CC(N)C(C)(C)[Si](C)(C)c1ccccc1</smiles><smiles>C[NH3+]</smiles><smiles>CC(I)C(C)(C)[Si](C)(C)c1ccccc1</smiles>

$\operatorname{roc}-3$

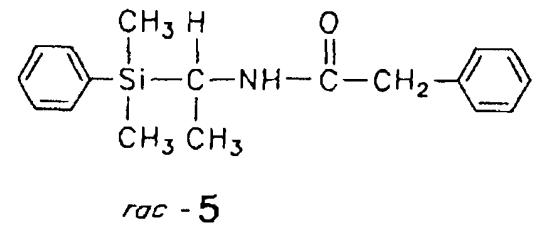

Scheme 1.

ref. 12 (in this context, see also refs. 13-15), the (chloromethyl)silane 1 was deprotonated by treatment with sec-butyllithium $/ N, N, N^{\prime}, N^{\prime}$-tetramethylethylenediamine in tetrahydrofuran to give [chloro(dimethylphenylsilyl)methyl]lithium, which when treated with methyl iodide gave the (1-chloroethyl)silane rac-2 (yield 66\%). Treatment of rac-2 with sodium iodide in acetone (cf. ref. 16) gave the (1iodoethyl)silane rac-3 (yield $81 \%$; ref. 16: 78\%), which was then converted into the corresponding (1-aminoethyl)silane $\mathrm{rac}-4$ by reaction with ammonia under pressure, following a procedure described in ref. 16. Under optimized reaction conditions (see Experimental section), rac-4 was obtained in $94 \%$ yield (ref. 16: $23-62 \%$ ). In the last step, the [1-(phenylacetamido)ethyl]silane rac-5 was prepared by acylation of rac-4 with phenylacetic acid using 4,6-diphenylthieno[3,4-d]-1,3-dioxol-2-one 5,5-dioxide (Steglich's reagent [17-19]) as carboxyl activating agent (yield 82\%).

The silane rac-5 was synthesized for the first time (total yield $41 \%$, based on 1 used). The precursors rac-2-rac-4 have been described previously [16], but in the present paper a new method for the preparation of rac-2 is described, as are optimized procedures for the synthesis of rac-3 and rac-4.

\section{Enzymatic hydrolysis of rac-5}

Preliminary experiments have shown that ( $R$ )-4 can be prepared by enantioselective hydrolysis of rac-5 with immobilized PGA as biocatalyst (Scheme 2). The conditions for this bioconversion were optimized by analytical-scale studies [11], on 


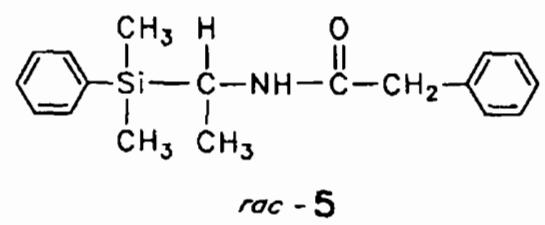

Penicillin $G$ Acylase

(E.C. 3.5.1.11)

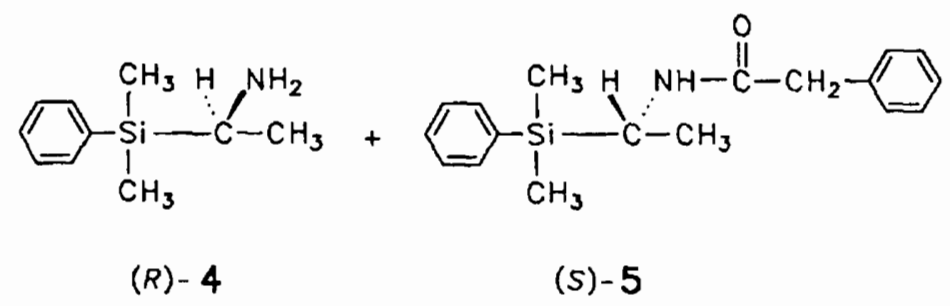

Scheme 2.

the basis of which the following conditions were chosen for a conversion of rac-5 on a preparative scale (225 $\mathrm{mg}$ scale): 1.81 of $0.1 \mathrm{M}$ potassium phosphate buffer/ dimethyl sulfoxide $(99.5 / 0.5, \mathrm{v} / \mathrm{v})$ as reaction medium, $\mathrm{pH} 7.5$, temperature $37^{\circ} \mathrm{C}$, substrate concentration $0.42 \mathrm{mmol} / 1,90 \mathrm{~g}$ immobilized PGA [100 U/g, related to the hydrolysis of penicillin G; acrylic beads (Eupergit $C$ )], reaction time 3 hours (about $45 \%$ conversion of rac-5). After termination of the enzymatic hydrolysis by addition of ethyl acetate, the product $(R)-4$ was separated from the unchanged substrate and isolated in $40 \%$ yield (related to rac-5) with an enantiomeric purity of $92 \%$ ee. The unchanged starting material $(S)-5$ was recovered in $50 \%$ yield (related to rac-5).

The absolute configuration and enantiomeric purity of the product $(R)-4$ were determined, after derivatization with $(S)$ - $\alpha$-methoxy- $\alpha$-trifluoromethylphenylacetic acid [( $S)$-MTPA], by ${ }^{1} \mathrm{H}$ NMR spectroscopic studies (see ref. 20) and GLC, respectively. For comparison, a $1: 1$ mixture of the diastereomeric [( $S)$-MTPA] amides of $(R)-4$ and $(S)-4$ was prepared from rac-4. These amides were obtained by reaction of 4 with $(S)$-MTPA in the presence of $N, N^{\prime}$-dicyclohexylcarbodiimide and a catalytic amount of (4-dimethylamino)pyridine.

The results described here demonstrate that enantioselective biotransformations, with immobilized enzymes as biocatalyst, may be useful for the synthesis of optically active organosilicon compounds on a preparative scale.

\section{Experimental}

\section{(a) Chemical syntheses}

All reactions were performed in dried solvents under dry nitrogen. Melting points were determined with a Reichelt Thermovar apparatus (without correction). ${ }^{1} \mathrm{H}$ and ${ }^{13} \mathrm{C}$ NMR spectra were recorded on a Bruker AM-400 spectrometer operating at 400.1 and $100.6 \mathrm{MHz}$, respectively. Chemical shifts (ppm) were measured relative to the internal standard $\mathrm{Si}\left(\mathrm{CH}_{3}\right)_{4}\left({ }^{1} \mathrm{H}\right.$ and $\left.{ }^{13} \mathrm{C}, \delta 0\right)$. Assignment of the ${ }^{13} \mathrm{C}$ data was 
assisted by DEPT experiments. ${ }^{19} \mathrm{~F}$ and ${ }^{29} \mathrm{Si}$ NMR spectra were recorded on a Bruker AC-200 spectrometer operating at 188.3 and $39.8 \mathrm{MHz}$, respectively. Chemical shifts (ppm) were measured with respect to those of $\mathrm{CFCl}_{3}\left({ }^{19} \mathrm{~F}, \delta 0\right)$ or $\mathrm{Si}\left(\mathrm{CH}_{3}\right)_{4}\left({ }^{29} \mathrm{Si}, \delta 0\right)$ as external standard. Mass spectra were obtained with a Finnigan MAT 8430 mass spectrometer (EI MS, $70 \mathrm{eV}$ ); the $m / z$ values given refer to the isotopes ${ }^{1} \mathrm{H},{ }^{12} \mathrm{C},{ }^{14} \mathrm{~N},{ }^{16} \mathrm{O},{ }^{28} \mathrm{Si},{ }^{35} \mathrm{Cl}$ and ${ }^{127} \mathrm{I}$.

(Chloromethyl)dimethylphenylsilane (1)

Synthesis according to ref. 14.

\section{rac-(1-Chloroethyl)dimethylphenylsilane (rac-2)}

A $1.4 M$ solution $(164 \mathrm{ml})$ of sec-butyllithium in cyclohexane/isopentane $(92 / 8$, $\mathrm{v} / \mathrm{v} ; 0.23 \mathrm{~mol} \mathrm{sec-butyllithium})$ and $24.1 \mathrm{~g}(0.21 \mathrm{~mol}) N, N, N^{\prime}, N^{\prime}$-tetramethylethylenediamine were successively added dropwise to a stirred solution of $40.0 \mathrm{~g}(0.217$ mol) 1 in $260 \mathrm{ml}$ of THF at $-78^{\circ} \mathrm{C}$ during periods of $1.5 \mathrm{~h}$ and $20 \mathrm{~min}$, respectively. After $1 \mathrm{~h}$ stirring at $-78^{\circ} \mathrm{C}$ the mixture was allowed to warm to $-55^{\circ} \mathrm{C}$ and a solution of $41.2 \mathrm{~g}(0.29 \mathrm{~mol})$ of methyl iodide in $70 \mathrm{ml}$ of THF was added dropwise during $1 \mathrm{~h}$. When the addition was complete, stirring was continued for $40 \mathrm{~min}$ at $-40^{\circ} \mathrm{C}$ and an additional $16 \mathrm{~h}$ at room temperature. The mixture was then added carefully (ice cooling) to $700 \mathrm{ml}$ of saturated aqueous $\mathrm{NH}_{4} \mathrm{Cl}$. The organic phase was separated and the aqueous layer extracted three times with 350 $\mathrm{ml}$ portions of diethyl ether. The combined organic extracts were washed with water and dried over $\mathrm{Na}_{2} \mathrm{SO}_{4}$, and the solvent was then removed in vacuo and the residue fractionally distilled to yield $28.3 \mathrm{~g}(66 \%)$ of a colourless liquid, b.p. $76^{\circ} \mathrm{C} / 6 \mathrm{Tor}$ (ref. 16: b.p. $90-97^{\circ} \mathrm{C} / 4$ Torr). ${ }^{1} \mathrm{H}$ NMR $\left(\mathrm{CDCl}_{3}\right): \delta 0.40$ (s, 3H; $\left.\mathrm{SiCH}_{3}\right), 0.41$ (s, $\left.3 \mathrm{H} ; \mathrm{SiCH}_{3}\right), 1.46\left(\mathrm{~d},{ }^{3} \mathrm{~J}(\mathrm{HH}) 7.6 \mathrm{~Hz}, 3 \mathrm{H} ; \mathrm{CCH}_{3}\right), 3.53(\mathrm{q}, 3(\mathrm{HH}) 7.6 \mathrm{~Hz}, 1 \mathrm{H}$ : $\mathrm{SiCH}(\mathrm{Cl}) \mathrm{C}), 7.4-7.6\left(\mathrm{~m}, 5 \mathrm{H} ; \mathrm{SiC}_{6} \mathrm{H}_{5}\right) \cdot{ }^{13} \mathrm{C} \mathrm{NMR}\left(\mathrm{CDCl}_{3}\right): \delta-6.1\left(\mathrm{SiCH}_{3}\right),-5.0$ $\left(\mathrm{SiCH}_{3}\right), 20.1\left(\mathrm{CCH}_{3}\right), 45.0(\mathrm{SiCH}(\mathrm{Cl}) \mathrm{C}), 127.9\left(\mathrm{C}_{m}, \mathrm{SiC}_{6} \mathrm{H}_{5}\right), 129.6\left(\mathrm{C}_{p}, \mathrm{SiC}_{6} \mathrm{H}_{5}\right)$, $134.2\left(\mathrm{C}_{o}, \mathrm{SiC}_{6} \mathrm{H}_{5}\right), 135.7\left(\mathrm{C}_{\mathrm{i}}, \mathrm{SiC}_{6} \mathrm{H}_{5}\right) . \mathrm{MS}: m / z 198\left(1 \%, M^{+}\right), 135(100 \%$. $\left.M^{+}-\mathrm{CH}(\mathrm{Cl}) \mathrm{CH}_{3}\right)$. Anal. Found: $\mathrm{C} 60.4 ; \mathrm{H} \mathrm{7.5.} \mathrm{C}_{10} \mathrm{H}_{15} \mathrm{ClSi}(198.8)$ calc.: $\mathrm{C} 60.43$; $\mathrm{H} 7.61 \%$.

\section{rac-(1-Iodoethyl)dimethylphenylsilane (rac-3)}

The procedure was as described in ref. 16 . Sodium iodide $(83.9 \mathrm{~g} ; 0.56 \mathrm{~mol})$ was added to a solution of $40.0 \mathrm{~g}(0.20 \mathrm{~mol}) \mathrm{rac}-2$ in $200 \mathrm{ml}$ of acetone and the mixture was stirred under reflux for 11 days. It was then cooled to room temperature, $200 \mathrm{ml}$ of water were added and the mixture extracted three times with $250 \mathrm{ml}$ portions of diethyl ether. The combined organic extracts were dried over $\mathrm{Na}_{2} \mathrm{SO}_{4}$, the solvent was removed in vacuo, and the residue fractionally distilled to yield $47.4 \mathrm{~g} \mathrm{(81 \% )}$ of a colourless liquid, b.p. $66^{\circ} \mathrm{C} / 0.2$ Torr (ref. 16 : yield $78 \%$, b.p. $130^{\circ} \mathrm{C} / 10$ Torr). ${ }^{1} \mathrm{H}$ $\operatorname{NMR}\left(\mathrm{CDCl}_{3}\right): \delta 0.49\left(\mathrm{~s}, 6 \mathrm{H} ; \mathrm{SiCH}_{3}\right), 1.83\left(\mathrm{~d},{ }^{3} \mathrm{~J}(\mathrm{HH}) 7.8 \mathrm{~Hz}, 3 \mathrm{H} ; \mathrm{CCH}_{3}\right), 3.41$ (q, $\left.{ }^{3} J(\mathrm{HH}) 7.8 \mathrm{~Hz}, 1 \mathrm{H} ; \mathrm{SiCH}(\mathrm{I}) \mathrm{C}\right), 7.4-7.6\left(\mathrm{~m}, 5 \mathrm{H} ; \mathrm{SiC}_{6} \mathrm{H}_{5}\right) .{ }^{13} \mathrm{C} \mathrm{NMR}\left(\mathrm{CDCl}_{3}\right): \delta$ - $5.0\left(\mathrm{SiCH}_{3}\right),-3.1\left(\mathrm{SiCH}_{3}\right), 11.7\left(\mathrm{CCH}_{3}\right), 22.2(\mathrm{SiCH}(\mathrm{l}) \mathrm{C}), 127.9\left(\mathrm{C}_{m}, \mathrm{SiC}_{6} \mathrm{H}_{5}\right)$, $129.6\left(\mathrm{C}_{p}, \mathrm{SiC}_{6} \mathrm{H}_{5}\right), 134.1\left(\mathrm{C}_{o}, \mathrm{SiC}_{6} \mathrm{H}_{5}\right), 135.8\left(\mathrm{C}_{i}, \mathrm{SiC}_{6} \mathrm{H}_{5}\right) . \mathrm{MS}: m / z 290(2 \%$, $M^{+}$), 135 (100\%, $\left.M^{+}-\mathrm{CH}(\mathrm{I}) \mathrm{CH}_{3}\right), \mathrm{C}_{10} \mathrm{H}_{15} \mathrm{ISi}(290.2)$.

\section{rac-( 1 -Aminoethyl)dimethylphenylsilane (rac-4)}

The procedure was a modification of that described in ref. 16. A $250 \mathrm{ml}$ glass tube charged with $12.1 \mathrm{~g}(41.7 \mathrm{mmol}) \mathrm{rac}-3$ and ca. $180 \mathrm{ml}$ of liquid ammonia was 
placed in a $250 \mathrm{ml}$ autoclave. When the autoclave was heated to $135^{\circ} \mathrm{C}$ a pressure of 70-75 bar was reached. The autoclave was kept for $2.5 \mathrm{~h}$ under these conditions and then allowed to cool to room temperature. After evaporation of the excess of ammonia, $30 \mathrm{ml}$ of a $6 \mathrm{~N}$ aqueous $\mathrm{NaOH}$ solution were added and the mixture was extracted four times with $70 \mathrm{ml}$ portions of diethyl ether. The combined organic layers were dried over $\mathrm{Na}_{2} \mathrm{SO}_{4}$, the solvent was removed in vacuo, and the residue (consisting of a mixture of a white solid and a colourless oil) was fractionally distilled to yield $7.00 \mathrm{~g}(94 \%)$ of a colourless liquid, b.p. $82^{\circ} \mathrm{C} / 0.1$ Torr (ref. 16: yield $23-62 \%$, b.p. $90-130^{\circ} \mathrm{C} / 2$ Torr), which partly crystallized at room temperature, to give a solid of m.p. $44-51^{\circ} \mathrm{C} .{ }^{1} \mathrm{H} \mathrm{NMR}\left(\mathrm{CDCl}_{3}\right): \delta 0.32\left(\mathrm{~s}, 3 \mathrm{H} ; \mathrm{SiCH}_{3}\right)$, 0.33 (s, 3H; $\mathrm{SiCH}_{3}$ ), 1.15 (d, ${ }^{3} J(\mathrm{HH}) 7.4 \mathrm{~Hz}, 3 \mathrm{H} ; \mathrm{CCH}_{3}$ ), 2.39 (broad 's', $2 \mathrm{H} ; \mathrm{NH}_{2}$ ), $2.53\left(\mathrm{q},{ }^{3} \mathrm{~J}(\mathrm{HH}) 7.4 \mathrm{~Hz}, 1 \mathrm{H} ; \mathrm{SiCH}(\mathrm{N}) \mathrm{C}\right), 7.3-7.6\left(\mathrm{~m}, 5 \mathrm{H} ; \mathrm{SiC}_{6} \mathrm{H}_{5}\right) .{ }^{13} \mathrm{C} \mathrm{NMR}$ $\left(\mathrm{CDCl}_{3}\right): \delta-5.9\left(\mathrm{SiCH}_{3}\right),-5.6\left(\mathrm{SiCH}_{3}\right), 19.6\left(\mathrm{CCH}_{3}\right), 36.0(\mathrm{SiCH}(\mathrm{N}) \mathrm{C}), 127.9$ $\left(\mathrm{C}_{m}, \mathrm{SiC}_{6} \mathrm{H}_{5}\right), 129.2\left(\mathrm{C}_{p}, \mathrm{SiC}_{6} \mathrm{H}_{5}\right), 134.1\left(\mathrm{C}_{o}, \mathrm{SiC}_{6} \mathrm{H}_{5}\right), 136.9\left(\mathrm{C}_{\mathrm{i}}, \mathrm{SiC}_{6} \mathrm{H}_{5}\right) .{ }^{29} \mathrm{Si}$ NMR $\left(\mathrm{CDCl}_{3}\right):-0.4$. MS: $m / z 179\left(3 \%, M^{+}\right), 44\left(100 \%, \mathrm{H}_{2} \mathrm{~N}=\mathrm{C}\left(\mathrm{CH}_{3}\right) \mathrm{H}^{+}\right)$. $\mathrm{C}_{10} \mathrm{H}_{17} \mathrm{NSi}$ (179.3).

rac-Dimethylphenyl[1-(phenylacetamido)ethyl] silane (rac-5)

A mixture of $1.00 \mathrm{~g}$ (3.06 mmol) 4,6-diphenylthieno[3,4-d]-1,3-dioxol-2-one 5,5dioxide (Steglich's reagent), $0.41 \mathrm{~g}(3.01 \mathrm{mmol})$ phenylacetic acid and $0.24 \mathrm{~g}$ (3.03 mmol) pyridine in $25 \mathrm{ml}$ of dichloromethane was stirred for $2 \mathrm{~h}$ at room temperature. Subsequently, $0.31 \mathrm{~g}(3.06 \mathrm{mmol})$ triethylamine were added, the solution turning orange-red. After $10 \mathrm{~min}$ stirring, a solution of $0.45 \mathrm{~g}(2.51 \mathrm{mmol}) \mathrm{rac}-4$ in $15 \mathrm{ml}$ of dichloromethane was added dropwise. Stirring was continued for $2 \mathrm{~h}$, giving a yellow solution. The mixture was extracted twice with $30 \mathrm{ml}$ portions of $20 \%$ aqueous citric acid, three times with $50 \mathrm{ml}$ portions of saturated aqueous $\mathrm{NaHCO}_{3}$ solution, then again with $30 \mathrm{ml}$ of $20 \%$ aqueous citric acid solution, and finally with $30 \mathrm{ml}$ of water. The organic layer was dried over $\mathrm{MgSO}_{4}$ and the solvent removed in vacuo. Recrystallization of the remaining solid from acetonitrile at $-20^{\circ} \mathrm{C}$ gave $0.61 \mathrm{~g}(82 \%)$ of white needles, m.p. $85^{\circ} \mathrm{C} .{ }^{1} \mathrm{H} \mathrm{NMR}\left(\mathrm{CDCl}_{3}\right): \delta 0.19$ $\left(\mathrm{s}, 3 \mathrm{H} ; \mathrm{SiCH}_{3}\right), 0.24\left(\mathrm{~s}, 3 \mathrm{H} ; \mathrm{SiCH}_{3}\right), 1.02\left(\mathrm{~d}, 3 \mathrm{~J}(\mathrm{HH}) 7.5 \mathrm{~Hz}, 3 \mathrm{H} ; \mathrm{CCH}_{3}\right), 3.39$ and $3.54\left(\mathrm{AB}\right.$ system, $\left.{ }^{2} J(\mathrm{HH}) 15.9 \mathrm{~Hz}, 2 \mathrm{H} ; \mathrm{CCH}_{2} \mathrm{C}\right), 3.73\left(\mathrm{dq},{ }^{3} J(\mathrm{HH}) 7.5 \mathrm{~Hz},{ }^{3} J(\mathrm{HH})\right.$ 9.6 Hz, 1H; $\mathrm{SiCH}(\mathrm{N}) \mathrm{C}), 5.0-5.1(\mathrm{~m}, 1 \mathrm{H} ; \mathrm{NH}), 7.1-7.4\left(\mathrm{~m}, 10 \mathrm{H} ; \mathrm{SiC}_{6} \mathrm{H}_{5}, \mathrm{CC}_{6} \mathrm{H}_{5}\right)$. ${ }^{13} \mathrm{C}$ NMR $\left(\mathrm{CDCl}_{3}\right): \delta-5.4\left(\mathrm{SiCH}_{3}\right), 16.4\left(\mathrm{CCH}_{3}\right), 34.4(\mathrm{SiCH}(\mathrm{N}) \mathrm{C}), 44.1$ $\left(\mathrm{CCH}_{2} \mathrm{C}\right), 127.3,128.0,129.0,133.8,135.1$ and $135.6\left(\mathrm{SiC}_{6} \mathrm{H}_{5}, \mathrm{CC}_{6} \mathrm{H}_{5}\right), 170.3(\mathrm{CO})$. ${ }^{29} \mathrm{Si}$ NMR $\left(\mathrm{CDCl}_{3}\right): \delta$ - 1.7. MS: $m / z 297\left(56 \%, M^{+}\right), 135\left(100 \%, M^{+}-\right.$ $\left.\mathrm{CH}\left[\mathrm{N}(\mathrm{H}) \mathrm{C}(\mathrm{O}) \mathrm{CH}_{2} \mathrm{C}_{6} \mathrm{H}_{5}\right] \mathrm{CH}_{3}\right)$. Anal. Found: $\mathrm{C} 72.7 ; \mathrm{H} 7.9 ; \mathrm{N} 4.7 . \mathrm{C}_{18} \mathrm{H}_{23} \mathrm{NOSi}$ (297.5) calc.: C 72.68; H 7.79; N 4.71\%.

Preparation of the [(S)-MTPA] amides of 4, determination of their absolute configuration, and their separation by gas chromatography

A solution of $9.0 \mathrm{mg}(50 \mu \mathrm{mol}) 4$ (chemically prepared racemic 4 or the biotransformation product 4) in $0.5 \mathrm{ml}$ dichloromethane was added at room temperature to a stirred mixture of $14.1 \mathrm{mg}(60 \mu \mathrm{mol})(S)$ - $\alpha$-methoxy- $\alpha$-trifluoromethylphenylacetic acid [( $S)$-MTPA], $18.6 \mathrm{mg}(90 \mu \mathrm{mol}) \quad N, N^{\prime}$-dicyclohexylcarbodiimide and 1-2 mg (4-dimethylamino)pyridine in $4 \mathrm{ml}$ of dichloromethane. Stirring was continued until the reaction was complete [monitored by thin-layer chromatography (pre-coated plastic-backed plates, silica gel $60 \mathrm{~F}_{254}$, Merck 5735; dichloro- 
methane/diethyl ether $(1 / 1, v / v)]$. The suspension was centrifuged and the supernatant liquid isolated with a syringe and the solvent evaporated in vacuo. The residue was purified by preparative layer chromatography [pre-coated glass plates, silica gel 60 , Merck 13895; dichloromethane/diethyl ether $(1 / 1, v / v)]$. The resulting mixture of the diastereomeric [( $S)$-MTPA] amides of $(R)-4$ and $(S)-4$ was dissolved in benzene- $d_{6}$ and then analyzed by NMR spectroscopy. The absolute configuration of the $\mathrm{Si}-\mathrm{C}^{\star} \mathrm{H}(\mathrm{NHR})-\mathrm{C}$ skeleton of the [( $\left.S\right)$-MTPA] amides of $(R)-4$ and $(S)-4$ was assigned by the correlation method described in ref. 20.

[(S)-MTPA] amide of (R)-4. ${ }^{1} \mathrm{H}$ NMR $\left(\mathrm{C}_{6} \mathrm{D}_{6}: \delta 0.15\left(\mathrm{~s}, 3 \mathrm{H} ; \mathrm{SiCH}_{3}\right), 0.21(\mathrm{~s}\right.$, $\left.3 \mathrm{H} ; \mathrm{SiCH}_{3}\right), 0.91\left(\mathrm{~d},{ }^{3} \mathrm{~J}(\mathrm{HH}) 7.5 \mathrm{~Hz}, 3 \mathrm{H} ; \mathrm{CCH}_{3}\right), 3.00\left(\mathrm{q},{ }^{5} J(\mathrm{HF}) 1.5 \mathrm{~Hz}, 3 \mathrm{H}\right.$ : $\left.\mathrm{OCH}_{3}\right), 3.84\left(\mathrm{q},{ }^{3}(\mathrm{HH}) 7.5 \mathrm{~Hz}, 1 \mathrm{H} ; \mathrm{SiCH}(\mathrm{N}) \mathrm{C}\right), 6.3-6.4(\mathrm{~m}, 1 \mathrm{H}: \mathrm{NH}), 7.0-7.7(\mathrm{~m}$. $\left.10 \mathrm{H} ; \mathrm{SiC}_{6} \mathrm{H}_{5}, \mathrm{CC}_{6} \mathrm{H}_{5}\right) .{ }^{19} \mathrm{~F} \mathrm{NMR}\left(\mathrm{C}_{6} \mathrm{D}_{6}\right): \delta-68.7$.

[(S)-MTPA] amide of (S)-4. ${ }^{1} \mathrm{H}$ NMR $\left(\mathrm{C}_{6} \mathrm{D}_{6}: \delta 0.10\left(\mathrm{~s}, 3 \mathrm{H} ; \mathrm{SiCH}_{3}\right), 0.11(\mathrm{~s}\right.$, $\left.3 \mathrm{H} ; \mathrm{SiCH}_{3}\right), 0.97\left(\mathrm{~d},{ }^{3} \mathrm{~J}(\mathrm{HH}) 7.5 \mathrm{~Hz}, 3 \mathrm{H} ; \mathrm{CCH}_{3}\right), 3.05$ (q, ${ }_{5}^{5}(\mathrm{HF}) 1.6 \mathrm{~Hz}, 3 \mathrm{H}$; $\left.\mathrm{OCH}_{3}\right) .3 .78\left(\mathrm{q},{ }^{3}(\mathrm{HH}) 7.5 \mathrm{~Hz}, 1 \mathrm{H} ; \mathrm{SiCH}(\mathrm{N}) \mathrm{C}\right), 6.2-6.3(\mathrm{~m}, 1 \mathrm{H} ; \mathrm{NH}) .7 .0-7.7(\mathrm{~m}$, 10H: $\left.\mathrm{SiC}_{6} \mathrm{H}_{5}, \mathrm{CC}_{6} \mathrm{H}_{5}\right) .{ }^{19} \mathrm{~F}$ NMR $\left(\mathrm{C}_{6} \mathrm{D}_{6}\right): \delta-68.9$.

For separation of the $[(S)-\mathrm{MTPA}]$ amides of 4 by gas chromatography a Chrompack instrument (model 436) was used [capillary column Cp-Sil-5 CB, $10 \mathrm{~m}$, $0.25 \mathrm{~mm}$; split injection, $270^{\circ} \mathrm{C}$; carrier gas hydrogen; temperature programmme $150-200^{\circ} \mathrm{C}\left(6^{\circ} / \mathrm{min}\right)$; FID, $300^{\circ} \mathrm{C}$; retention time 3.7 (derivative of $\left.(S)-4\right)$ and 4.0 min, respectively (derivative of $(R)-4)$ ]. The samples used for these GLC studies were obtained as follows: After derivatization of chemically or enzymatically prepared 4 with $(S)$-MTPA by the procedure described above, the resulting reaction mixture was centrifuged and $1 \mu$ l of the supernatant was analyzed directly without further purification.

\section{(b) Bioconversion}

Immobilized penicillin $\mathrm{G}$ acylase $(90 \mathrm{~g}$; $9000 \mathrm{U}$, related to the hydrolysis of penicillin G) from Escherichia coli $5 \mathrm{~K}$ (pHM 12) [E.C. 3.5.1.11; immobilized on Eupergit $\mathrm{C}$ (Röhm, Germany)] was suspended at $37^{\circ} \mathrm{C}$ in 1.81 of $0.1 \mathrm{M}$ potassium phosphate buffer ( $\mathrm{pH} 7.5$ ). The reaction was started by adding a solution of $225 \mathrm{mg}$ ( $756 \mu \mathrm{mol}$ ) rac -5 in $9 \mathrm{ml}$ of DMSO to the mechanically stirred enzyme suspension. After $3 \mathrm{~h}$ stirring the reaction was terminated by addition of $100 \mathrm{ml}$ of ethyl acetate and subsequent removal of the enzyme preparation by filtration (Büchner funnel). The biocatalyst was washed successively three times with $200 \mathrm{ml}$ of ethyl acetate and three times with $300 \mathrm{ml}$ of the buffer solution. The organic and aqueous solutions were combined and the aqueous layer was adjusted to $\mathrm{pH}<3$ with $6 \mathrm{~N}$ hydrochloric acid. The organic layer was separated and washed twice with ca. 200 $\mathrm{ml}$ of $6 \mathrm{~N}$ aqueous $\mathrm{KOH}$ solution to remove the DMSO, phenylacetic acid, and $\mathrm{HCl}$. The organic extract was dried over $\mathrm{Na}_{2} \mathrm{SO}_{4}$ and the solvent evaporated; the solid crude product was purified by recrystallization from acetonitrile at $-20^{\circ} \mathrm{C}$ to yield $112 \mathrm{mg}$ ( $50 \%$, related to $\mathrm{rac}-5$ ) of the unchanged substrate 5 . The acidic aqueous layer containing the hydrochloride of the biotransformation product was adjusted to $\mathrm{pH} 10$ with $6 \mathrm{~N}$ aqueous $\mathrm{KOH}$ solution and then extracted with $800 \mathrm{ml}$ of ethyl acetate. The organic layer was washed twice with ca. $200 \mathrm{ml}$ of $6 \mathrm{~N}$ aqueous $\mathrm{KOH}$ solution to remove the DMSO and then dried over $\mathrm{Na}_{2} \mathrm{SO}_{4}$. After removal of the solvent in vacuo the crude product was purified by Kugelrohr distillation $\left(80^{\circ} \mathrm{C} / 0.1\right.$ Torr) to give $54.3 \mathrm{mg}(40 \%$, related to rac -5$)$ of $(R)-4$ as a colourless 
liquid which partly crystallized at room temperature to give a solid of m.p. $78^{\circ} \mathrm{C}$. The spectroscopic properties of the product were identical with those of chemically prepared rac-4 (see above).

${ }^{2} \mathrm{H}$ NMR spectroscopic studies and GLC analyses of the biotransformation product, after derivatization with ( $S$ )-MTPA (see above), revealed the $(R)$-configuration for the excess enantiomer of $\mathbf{4}$ and an enantiomeric purity of $92 \%$ ee.

\section{Acknowledgements}

This work was supported by the Deutsche Forschungsgemeinschaft and the Fonds der Chemischen Industrie. The immobilized biocatalyst used was donated by Röhm Pharma GmbH, Germany.

\section{References}

1 R. Tacke, H. Linoh, B. Stumpf, W.-R. Abraham, K. Kieslich and L. Ernst, Z. Naturforsch., 38b (1983) 616.

2 C. Syldatk, H. Andree, A. Stoffregen, F. Wagner, B. Stumpf, L. Ernst, H. Zilch and R. Tacke, Appl. Microbiol. Biotechnol., 27 (1987) 152.

3 C. Syldatk, A. Stoffregen, F. Wuttke and R. Tacke, Biotechnol. Lett., 10 (1988) 731.

4 R. Tacke, H. Hengelsberg, H. Zilch and B. Stumpf, J. Organomet. Chem., 379 (1989) 211.

5 C. Syldatk, J. Fooladi, A. Stoffregen, R. Tacke, F. Wagner and M. Wettern, in J.A.M. de Bont, J. Visser, B. Mattiasson and J. Tramper (Eds.), Physiology of Immobilized Cells, Elsevier, Amsterdam, 1990, pp. 377-385.

6 R. Tacke, S. Brakmann, F. Wuttke, J. Fooladi, C. Syldatk and D. Schomburg, J. Organomet. Chem., 403 (1991) 29.

7 K. Fritsche, C. Syldatk, F. Wagner, H. Hengelsberg and R. Tacke, Appl. Microbiol. Biotechnol., 31 (1989) 107.

8 R. Tacke and B. Becker, Main Group Met. Chem., 10 (1987) 169.

9 C. Syldatk, A. Stoffregen, A. Brans, K. Fritsche, H. Andree, F. Wagner, H. Hengelsberg, A. Tafel, F. Wuttke, H. Zilch and R. Tacke, in H.W. Blanch and A.M. Klibanov (Eds.), Enzyme Engineering 9. Annals of the New York Academy of Sciences, Vol. 542, The New York Academy of Sciences, New York, 1988, pp. 330-338.

10 R. Tacke and H. Linoh, in S. Patai and Z. Rappoport (Eds.), The Chemistry of Organic Silicon Compounds, Part 2, John Wiley, Chichester, 1989, pp. 1143-1206.

11 K. Fritsche, H. Hengelsberg, C. Syldatk, R. Tacke and F. Wagner, in D. Behrens and A.J. Driesel (Eds.), DECHEMA Biotechnology Conferences, Vol. 3, Part A, VCH Verlagsgesellschaft, Weinheim, 1989, pp. 149-152.

12 C. Burford, F. Cooke, E. Ehlinger and P. Magnus, J. Am. Chem. Soc., 99 (1977) 4536.

13 D. Seyferth, E.M. Hanson and F.M. Armbrecht, Jr., J. Organomet. Chem., 23 (1970) 361.

14 G.L. Larson, R. Argüelles, O. Rosario and S. Sandoval, J. Organomet. Chem., 198 (1980) 15.

15 Du Pont de Nemours (inventor: W.K. Moberg), U.S. Patent 4,496,551 (29th January 1985); Chem. Abstr., 98 (1983) 198430e.

16 R.J. Fessenden and M.D. Coon, J. Med. Chem., 7 (1964) 561.

17 O. Hollitzer, A. Seewald and W. Steglich, Angew. Chem., 88 (1976) 480; Angew. Chem., Int. Ed. Engl., 15 (1976) 444.

18 H. Schmidt, O. Hollitzer, A. Seewald and W. Steglich, Chem. Ber., 112 (1979) 727.

19 G. Schnorrenberg and W. Steglich, Angew. Chem., 91 (1979) 326; Angew. Chem., Int. Ed. Engl., 18 (1979) 307.

20 J.A. Dale and H.S. Mosher, J. Am. Chem. Soc., 95 (1973) 512. 